\title{
A Study on the Reform of Grass-Root Trade Unions and the Promotion of Collective Bargaining in China
}

\author{
Cheng Liu \\ School of Law and Political Science, Shanghai Normal University, Shanghai, China
}

Email address :

liuchengss@sina.com

To cite this article:

Cheng Liu. A Study on the Reform of Grass-root Trade Unions and the Promotion of Collective Bargaining in China. Journal of Human Resource Management. Vol. 6, No. 3, 2018, pp. 103-110. doi: 10.11648/j.jhrm.20180603.13

Received: September 26, 2018; Accepted: October 12, 2018; Published: November 6, 2018

\begin{abstract}
In China, the actual union cadre appointment system formed during the planned economy period and the content of the work of the trade unions centered on welfare and entertainment must be changed, and the trade union cadres who have become lazy and silly under the planned economy system must be retrained or adjusted. And there shall be an incentive and restraint mechanism to make them work hard. At present, the most important measure to safeguard workers' rights and interests in China is to activate grass-root trade unions through reform; activating grass-root trade unions is also a prerequisite for promoting collective bargaining. The reform of grass-root trade unions is not only inevitable and necessary, but also feasible; the main measures for grass-root trade union reform are direct election of grass-root trade unions and representative litigation of trade unions on behalf of individual workers. The promotion of collective bargaining cannot be separated from the grass-root trade union reform, and the way of collective bargaining itself is also very important. Resulted from local conditions, Guangdong Model and Zhejiang Model are good examples in collective bargaining. Guangdong Model is a strike-leading model, where industrial disputes begin with a strike, and the employer advocated collective bargaining follows as a result of the strike; Zhejiang Model is a group job-hopping leading model, where the industrial disputes begin with group job-hopping or group sabotage, and the sectoral trade union advocated collective bargaining follows as a result of joint-pricing of employers. All localities ought to choose the right way according to local conditions.
\end{abstract}

Keywords: Grass-Root Trade Union, Direct Election, Representative Litigation, Collective Bargaining

\section{Introduction}

The People's Republic of China (China for short) is a very big developing country. There are great differences in different provinces and cities which are at different stages of development and have their own economic and social characteristics. The Communist Party of China (CPC for short) is the ruling Party and All-China Federation of Trade Unions (ACFTU for short) is similar to a department of CPC Central Committee. ACFTU is the sole trade union in China, and all trade unions, including federation of trade unions, industrial trade unions and grassroot trade unions inside companies, are its branches. Meanwhile, provincial and municipal-level federations of trade unions are mainly led by local CPC committees, especially in chairs' appointment. The collective agreements, which are called collective contracts, are mainly concluded at the company-level.

From late 1990s on, there have been grass-root trade union reform and collective bargaining in China (Although the earliest pilots of direct election of grass-root trade unions took place in Lishu county of Jilin province in 1984 and Shenzhen in 1986, the large scale pilots came into being in late 1900s to early 2000s) [1]; Guangdong Model and Zhejiang Model are good examples. Although the traditional model of Welfare and Entertainment Trade Union still accounts for the majority, and the reform nearly stopped in recent years, Guangdong Model and Zhejiang Model will surely dominate China in the near future (ACFTU also thinks that direct election of trade unions is the choice of the future) [2], because they formed in practice and there would be no other choice to maintain long-term social stability.

In the past 20 years, much attention has been paid to Guangdong province and Zhejiang province for they have different economic characteristics and then have different characteristics in labor and employment relations as well as industrial disputes. A lot of workers, employers, middle ranking managers, trade union leaders and government 
officers have been visited in these two provinces. This paper is the result of long-term observation and thought.

\section{The Inevitability and Necessity of Grass-Root Trade Unions' Reform}

The trade unions' reform focused on grass-root trade unions is not only the requirement of the transformation of economic system, but also the requirement of the role of ACFTU (All-China Federation of Trade Unions, the sole trade union in China) set by the Communist Party of China (CPC) Central Committee. Therefore, it is inevitable. At the same time, grass-roots trade unions' reform is also the common requirement of the ruling party, trade unions, and workers. And the reform is also a prerequisite for the promotion of collective bargaining. So it is necessary.

\subsection{The Inevitability of Grass-Root trade Unions' Reform}

\subsubsection{Grass-Root Trade Unions' Reform Is the Requirement of the Transformation of Economic System}

In the period of planned economy, all enterprises were affiliated to the government, being extensions of the administrative agencies. Therefore, the government could protect workers directly. In consequence, the Chinese trade unions have degenerated into dispensable Welfare Trade Unions and Entertainment Trade Unions. After the implementation of the market economy system, enterprises are no longer attached to the government. The government can only coordinate the labor-management relations medially and cannot protect the workers directly. This requires the trade unions to restore its nature and return to its original role, protecting workers' interests through collective bargaining, and sharing the rights with employers to let the workers share the fruits of enterprises' development. So, the actual union cadre appointment system formed during the planned economy period and the content of the work of the trade unions centered on welfare and entertainment must be changed, and the trade union cadres who have become lazy (unwilling to work) and silly (incapable to work) under the planned economy system must be retrained or adjusted. And there shall be an incentive and restraint mechanism to make them work hard. In particular, grass-root trade unions shall not only undertake the mission of collective bargaining, but also undertake the mission of implementing labor law and labor policy that all levels of federation of trade unions participate in making. If grass-root trade unions are not reformed, they will not only fail to satisfy the needs of workers to share the achievements of economic development, but also fail to safeguard the workers' rights granted by labor laws and regulations.

In fact, the All-China Federation of Trade Unions has long been aware of the inevitability of grassroot trade unions' reform. As early as 1997, ACFTU (All-China Federation of Trade Unions) has required that all trade unions must follow the relevant provisions of the Trade Union Law and the
Constitution of the All-China Federation of Trade Unions to improve the democratic election system and change the factual existence of appointment system in some localities and units [3]. The All-China Federation of Trade Unions would also take "strengthening the vitality of the grass-root trade unions as a central task, and striving to realize the massification and democratization of trade unions" as one of the principles that should be seriously adhered to in the reform and construction of trade unions[3]. The All-China Federation of Trade Unions also confirmed that "The guiding ideology of trade union reform and construction is to reform gradually the trade unions' organizational system, operational mechanism, activities and related systems which are not adapted to the requirements of the socialist market economy, guided by Deng Xiaoping Theory and the Party's basic line". The All-China Federation of Trade Unions also required that "The trade unions inside foreign-invested enterprises and private enterprises should carry out their work in accordance with the characteristics of their enterprises, with their focus on collective bargaining on behalf of employees and signing collective contracts as well as the legal protection of employees in accordance with the law". "Improve the democratic system of grass-root trade union and promote the massification and democratization of grass-roots trade unions." "Grass-root trade unions should abide by the Trade Union Law, Constitution of the All-China Federation of Trade Unions, the Provisional Regulation on Election of Grassroot Trade Unions and the Interim Provision on the Permanent Representatives System for Grassroot Trade Unions' Representative Assembly issued by the All-China Federation of Trade Unions, improve the democratic election system, and establish permanent representation of the Representative Assembly. The grassroot trade union committees' chairperson and vice chairpersons must be democratically elected. The trade union's chairman and deputy chairmen of the small and medium-sized enterprises and institutions shall be democratically elected directly by the representative assembly." [3].

\subsubsection{Grass-Root Trade Unions' Reform Is the Requirement of the CPC Central Committee for the Positioning of Trade Unions}

The CPC Central Committee's positioning of trade unions is reflected in the Constitution of the All-China Federation of Trade Unions and Trade Union Law. The General Rules of the Constitution of the All-China Federation of Trade Unions stipulates, "Chinese trade unions are mass organizations of the working class combined by the workers voluntarily led by the Communist Party of China. They are bridges and bonds between the Party and the staff and workers. They are important social pillars of the state political power, and represent the interests of members and workers. The basic duty of Chinese trade unions is to safeguard the legitimate rights and interests of workers." Article 2 of the Trade Union Law stipulates, "The All-China Federation of Trade Unions and its affiliated trade unions represent the interests of workers and safeguard the legitimate rights and interests of 
workers in accordance with the law." Article 6 states, "It is the basic duty of trade unions to protect workers' lawful rights and interests." Obviously, the position of the trade unions by the CPC Central Committee is the bridges and bonds between the Party and the staff and workers, and the representatives and the defenders of the interests of members and workers.

However, the reality is that most of the grass-root trade unions still remain Wealth Trade Unions and Entertainment Trade Unions of the planned economy period, or simply exist in name only, and thus are not accepted by workers. As a result, federations of trade unions at all levels have become the bridges and bonds between the Party and grass-root trade unions. Actually, the bridges and bonds between grass-root trade unions and the staff and workers have been broken. Furthermore, grass-root trade unions have become spectators or passersby of the interests of members and workers. It is thus obvious that the grass-root trade unions' reform is the requirement of the $\mathrm{CPC}$ Central Committee for the positioning of trade unions; and grass-root trade unions' reform is also the key for Chinese trade unions to reach their own target.

\subsection{The Necessity of Grass-Roots Trade Unions' Reform}

\subsubsection{Grass-Root Trade Unions' Reform Is a Prerequisite for Promoting Collective Bargaining}

Although the ILO (International Labor Organization) Workers' Representatives Convention, the Chinese Labor Law, and the labor laws of some countries allow non-union worker representatives to take part in collective bargaining, the Workers' Representatives Convention and national labor laws generally have restrictive provisions for them. In other words, collective bargaining without trade unions cannot become the mainstream of collective bargaining. The mainstream of collective bargaining is the collective bargaining that trade unions represent workers. Therefore, in order to promote collective bargaining in an all-round way, the existing trade unions should be brought into full play. First of all, grass-root trade unions should be activated through reform so as to promote collective bargaining effectively and prevent collective contracts from becoming formalistic. Based on that, the reform of sectoral trade unions shall be gradually promoted, and then collective bargaining can protect workers' interests better. It is clear that the grass-root trade unions' reform is a prerequisite for promoting collective bargaining.

\subsubsection{Grass-Root Trade Unions' Reform Is Practical Demand and an Urgent Requirement of Workers}

It is also an urgent requirement of workers and practical demand to activate grass-root trade unions through reform so as to maintain their rights and improve working conditions by means of collective strength.

Under market economy conditions, the contradiction between the interests of enterprises and workers and the vulnerable position of workers in labor relations determine the necessity of the representation of trade unions, especially the representative litigation of trade unions. Only by affirming and safeguarding the representative litigation of trade unions, can the role of trade unions be brought into play, so as to balance labor-management relations and protect the legitimate rights and interests of workers effectively. In recent years, labor dispute cases have increased continuously, and more and more labor dispute cases have entered into judicial procedures. In fact, there is only part of the labor dispute cases that enter into judicial procedures. Since many workers lack the necessary financial resources and fear retaliation, they are actually forced to endure unfair treatment, especially migrant workers. The most effective way to solve this problem is to have trade unions represent them in litigation.

In private enterprises and foreign-funded enterprises, only by direct election of the trade union leaders can the problems of fake unions and puppet unions be avoided, and trade unions can become real representatives of workers' interests. Otherwise, if workers cannot determine the chairmen of grassroot trade unions, the chairmen will not have pressure and motive to safeguard the interests of the workers, nor will they take the risk of losing their own interests to offend the company's management for the benefit of the workers. Therefore, the grass-root trade unions' reform, which focuses on affirming the right and duty of trade unions to litigate on behalf of workers and direct election of grass-root trade unions, is the practical demand to make trade unions active so as to safeguard the interests of workers. Of course, it is also an urgent requirement of the workers. Our survey also indicates that workers strongly demand grass-roots trade unions' reform.

\subsubsection{Grass-Roots Trade Unions' Reform Is a Practical Option for China to Avoid the Emergence of Anti-Government Trade Unions}

Trade unions can be divided into unionist unions and anti-government unions (revolutionary trade unions). The unionist trade unions strive for workers' rights and interests based on the premise of labor-management cooperation, whose goal is to share the fruits of economic development equitably. Anti-government trade unions are the result of government-employer unity and the government's policy of anti-unionism, whose goal is to overthrow the government and bury capitalists. As far as the ruling Party CPC and the ACFTU are concerned, the trade unions' representation and protection of the interests of workers are also the need to maintain regime and prevent the emergence of anti-government trade unions. However, the reality is that the active role of trade unions at all levels in the making of labor legislation and labor policies are invisible to workers. What the workers can see is that grass-root trade unions exist in name only and cannot safeguard their rights and interests. With the lapse of time, the workers will surely start all over again and seek ways outside the system --- seeking to establish anti-government trade unions.

In addition, the practice has proved that without harmonious labor relations, there would be no social stability and harmony. Maintaining and realizing fairness and justice is the main task in constructing a harmonious society. Only by 
safeguarding and realizing social fairness and justice effectively can the people enjoy ease of mind, social relations in all aspects be coordinated and people's enthusiasm, initiative and creativity be brought into play and come out. Directly elected trade unions can exercise trade union representation of action to safeguard the legitimate rights and interests of workers rationally, thus avoid the intensification of conflicts and maintain the cooperative relations between employees and employers, which is conducive to social stability and harmony. "Under the modern market system and democratic system, trade unions can serve as a kind of social force for reconciliation and balance." [4] Therefore, the solution of the direct election of grass-root unions and the representation of trade unions to litigate on behalf of individual workers is also the need to maintain social stability and harmony. Apparently, the grass-roots trade unions' reform is a realistic option for China to avoid the appearance of anti-government trade unions, and also a requirement of the ruling Party CPC and ACFTU.

In addition, grass-root trade unions' reform that mainly focuses on confirming the trade unions' right of representative litigation (trade unions litigate on behalf of individual workers) and direct election of grass-root trade unions is also the need to promote the level of human rights protection, the need to safeguard the legitimate rights and interests of workers, the need to maintain social stability, and the need to secure sustainable economic development; it is also the need to safeguard the position of trade unions and to maintain and develop labor law lawyers' team.

\section{The Feasibility of Grass-Root Trade Unions' Reform}

The grass-root trade unions' reform that confirm the right and duty of trade union's representative litigation and the direct election of grass-root trade unions is not only indispensable, but also feasible, which is highlighted in the following aspects.

\subsection{There Is Sufficient Political and Legal Room for Grass-Root Trade Unions' Reform}

\subsubsection{Legal Room for Trade Union's Representative Litigation}

China's current laws and regulations not only leave room, but also open the way for the right and duty of trade union's representative litigation. The first is the Trade Union Law, and the second is judicial interpretation.

The current Trade Union Law stipulates the rights of trade union's litigation in four places. Article 20 of the Trade Union Law stipulates that "If a company violates a collective contract and infringes on the labor rights and interests of workers, the trade union may require the enterprise to assume its responsibilities according to law; the dispute arising from the performance of the collective contract can be negotiated. If the dispute cannot be settled, the trade union may submit an arbitration to the labor dispute arbitration institution. If the arbitration institution refuses to accept it or the trade union is not satisfied with the arbitral award, it may file a lawsuit before the people's court." This provision clarifies the trade union's right of representative litigation in the industrial dispute. Article 21 stipulates that "workers shall consider the violation of their labor rights and apply for labor dispute arbitration or bring a lawsuit before a people's court, and the trade union shall provide support and assistance." This provision implies that trade unions should finance labor lawsuits or file labor lawsuits. This means that when the rights of workers are violated, the trade unions should help the workers to sue. Article 49 stipulates that "A trade union considering who violates its lawful rights and interests by violating the provisions of this law shall have the right to submit it to the people's government or relevant departments for action or to file a lawsuit before a people's court." Article 54 stipulates that "Contravening the article 46 of this law, which stipulates that if funds and property that infringed on trade unions are not returned, the trade union may file a lawsuit before the people's court, requesting a return and compensation for the losses."[5] All of these articles involve two kinds of lawsuits, namely civil lawsuits and administrative lawsuits. When the infringer is a state organ, the trade union can file an administrative lawsuit; when the infringer is not a state organ, the trade union can file a civil suit.

The Interpretation of the Supreme People's Court on Several Issues Concerning the Application of the Trade Union Law of the People's Republic of China in the Civil Trial [6] stipulates that when the people's court hears relevant cases involving trade unions, it shall recognize the legal person status of a social group of the trade union established in accordance with the Trade Union Law. A trade union with legal personality independently enjoys civil rights and assumes civil obligations. The enterprises, public institutions, institutions that trade unions have established, and the established trade unions and the enterprises invested and established by the trade unions shall, in accordance with the provisions of laws and judicial interpretations, respectively bear their respective civil liabilities.

\subsubsection{Political and Legal Room for Direct Election of Grass-Root Trade Unions}

The political room is mainly manifested in the following aspects: First, Article 26 of the Constitution of the All-China Federation of Trade Unions stipulates that the rights of the trade union members' assembly or representatives assembly are: "(third) Election of grass-root trade union committee and fund review committee. (forth) to replace or dismiss representatives of workers and staff or the members of the trade union committee. "Article 27 stipulates, "Chairmen and deputy chairmen may be directly elected by the members' assembly or the representative assembly, or may be elected by the grass-root trade union committee. Article 15 of The Measures for the Establishment of the Chairman of the Trade Union of the Enterprise stipulates, "The chairman of a trade union of a company may be directly elected by the general 
assembly or the representative assembly, or elected by the trade union committee; he may be elected concurrently with the election of the trade union committee, or elected separately." Second, many localities have approved pilots for the direct election of grass-root trade unions, such as Zhejiang[7], Guangdong[8], Shenzhen[9], Shanghai[10], Liaoning Province[11] and so on.

The legal room is mainly manifested in Article 9 of the Trade Union Law which stipulates: "The trade union committees at all levels are democratically elected by the general assembly or the representative assembly." "A trade union general assembly or a representative assembly has the power to replace or dismiss its elected representatives or members of the trade union committee." The direct election, removal or dismissal of the members of the trade union committee and the indirect election, removal or dismissal of trade union committee members are all allowed by law.

\subsection{There Is Sufficient Experience for Grass-Root Trade Unions' Reform}

\subsubsection{The Practice of Trade Unions' Representative Litigation}

In addition to the existing laws and regulations laying the foundation for the representative action of trade unions, it is also feasible to confirm the trade unions' representative litigation from the perspective of litigation costs and practical experience. First, the trade union dues are $2 \%$ of the total wages of employees, so there are sufficient sources of funding to ensure the smooth conduct of litigation activities. Second, at present, most of the local federation of trade unions are engaged in free litigation for workers in the form of legal aid and have accumulated a lot of experience. According to the Workers Daily, from the beginning of 2000, Yiwu Federation of Trade Unions boldly explored and initially established a new mechanism for the protection of workers' rights and interests based on wages negotiation, mediation of disputes, participation in arbitration, and litigation agency as the basic means. [12] Yiwu's experience has been prominent in the construction of the legal aid mechanism and litigation mechanism - to get maximum policy room and biggest support of funds and personnel for the trade union's legal aid, and select a number of specialized labor dispute agents to take targeted training and cultivating. [12] In addition to the Yiwu Federation of Trade Unions, many local federation of trade unions also litigate in the form of legal aid to help employees free of charge. For example, the Shanghai Federation of Trade Unions files hundreds of lawsuits on behalf of workers free of charge every year. [13].

\subsubsection{The Practice of Direct Election of Grassroot Trade Unions}

The direct election of grassroot trade unions currently has pilots in most provinces and cities, especially in Zhejiang, Shenzhen and Guangdong, which already have got adequate experience.

The upsurge of "direct election of grassroot trade union chairpersons" began in Yuhang District of Hangzhou. By
$2003,70 \%$ of the large and medium-sized enterprises in the private enterprises in Yuhang District had implemented direct election of chairmanship of grass-root trade unions. [14].

In 2012, Shenzhen Federation of Trade Unions launched a pilot project aiming at 163 grassroot trade union committees whose terms of office have expired. "The trade unions at the municipal and district levels will establish a linkage mechanism and intervene in advance to ensure that the nomination and decision of the union chairman candidates are passed on to the hands of workers, and promote the direct election of the chairmen of grassroot trade unions actively and steadily." [15] So far, there have been about 5,000 companies where the chairmen of grassroot trade unions were directly elected in Guangdong province, accounting for $2 \%$ of the province's grass-root trade union committees. [8].

In addition, grassroot trade unions' reform also has its sufficient social foundation. On the one hand, more and more workers are organizing themselves for collective bargaining, showing workers' demand for active trade unions really on behalf of them and their dissatisfaction with the trade unions that are ineffective. On the other hand, more and more employers are unable to find negotiating opponents (it is impossible to quell labor conflicts with negotiating opponents covered) and hope that there will be trade unions to negotiate with on behalf of workers. Moreover, because the leaders of grassroot trade unions within the enterprise are economically subject to the management of the enterprise, it is generally impossible for them to make excessive claims. Thus it can be seen that not only the workers support the grassroot trade unions' reform, but also the capital resistance of the grassroot trade unions' reform can be completely overcome.

\section{The Measures of Grass-Root Trade Unions' Reform}

The key measures of grass-root trade unions' reform at present are the direct election of grass-root trade unions and the representative litigation of trade unions on behalf of individual workers, supplemented by other supporting measures.

\subsection{Direct Election of Grassroot Trade Unions}

The grassroot trade unions should be activated through direct election of union leaders. With regard to legislation that guarantees the direct election of grass-root trade unions, it is proposed that the amendments to the Trade Union Law make the following stipulations: The chairpersons and deputy chairpersons of grass-root trade unions should be directly elected by all trade union members. The candidates of chairperson can be recommended before election, or all members of the newly elected trade union committee are listed as chairperson candidates, or there is no candidates listed.

\subsection{Representative Litigation of Trade Unions}

The representative litigation or action of trade unions is 
also necessary to activate grassroot trade unions and achieve the effective exercises of trade unions' representation. Regarding legislation confirming the right and obligation of trade unions' representative litigation, it is proposed that the amendments to the Trade Union Law make the following provisions: According to Article 2 of the Trade Union Law and the relevant provisions of the Civil Procedure Law, trade unions have the right and obligation to represent laborers in labor dispute proceedings. Where a trade union represents an employee in a lawsuit, the people's court shall accept it; if a grassroot trade union refuses to represent an employee to participate in the lawsuit, the higher level trade union has the right to participate directly in the lawsuit on behalf of the employee, and the people's court shall permit it to participate in the lawsuit as plaintiff or defendant. If a laborer requests the representative litigation, the grassroot trade union shall conduct a review; if the request is reasonable, the grassroot trade union has the right and obligation to file the lawsuit representiweng the employee. If the grassroot trade union refuses to perform its litigation obligations, the laborer may appeal to the higher level trade union; if the higher level trade union thinks that the request is reasonable, it has the right to order the grassroot trade union to perform its obligation, or directly represent the employee to file the lawsuit, and the litigation costs shall be borne by the grassroot trade union. The higher-level trade unions and the labor administrative departments at all levels shall examine the trade unions' representative litigation on behalf of the employees, and impose penalties on the grass-root trade unions that refuse to perform their litigation obligation. [16].

\subsection{Other Supporting Measures}

The realization of trade unions' representation in collective bargaining needs to improve the negotiating ability of collective bargaining representatives. Therefore, it is necessary to strengthen collective bargaining training, including labor law knowledge, labor economics knowledge, human resource management knowledge, and negotiation skills. First, teaching staff training should be strengthened. Due to the late start of labor relations in China, both theoretical research and empirical research are still immature. It is necessary to invite foreign academics and experts to come to China to give lectures on collective bargaining and send out exchange students and visiting scholars to foreign countries to study collective barning. Second, the training of grassroot trade union cadres should be strengthened. Grassroots trade union cadres are the main source of collective bargaining representatives, but their knowledge and experience are much less than Human resource managers. Therefore, they should be the focus of training. Third, training for human resource managers should be strengthened for they are also the main source of collective bargaining representatives. Fourth, there should be various forms of advisory and counseling activities on collective bargaining to create conditions to raise the collective bargaining consciousness, knowledge and skills. [17].

In addition, bilateral exchanges and cooperation between trade unions with other countries should be strengthened, especially trade unions in developed countries.

\section{The Promotion of Collective Bargaining}

Considering that there are big differences across mainland China, especially in economic development, the route to promote collective bargaining should be adapted to local conditions, in particular economic conditions, and promoted in line with the characteristics of the local economic structure step by step. Generally speaking, there are two models of collective bargaining in China which are Guangdong Model and Zhejiang Model. These two models have different characteristics in disputes and causes of formation, so the routes to promote collective bargaining are also different.

\subsection{The Guangdong Model ${ }^{1}$}

According to my survey, combined with media reports and other scholars' research, the characteristics of industrial disputes of Guangdong Model can be summarized as follows: (1) Industrial disputes begin with a strike, and the employer advocated collective bargaining follows as a result of the strike; (2) The leaders of strikes are mainly middle-ranking managers;2 (3)The employers always fire strikers as a start, and finally forced to take part in collective bargaining as a result of a more fierce strike; (4) The local government and local federation of trade unions are involved in the process of industrial disputes and collective bargaining.

The causes of the formation of industrial relations of the Guangdong Model are: (1) High degree of marketization and strong self-consciousness of laborers; low proportion of state-owned enterprises and low wages of workers. (2) In terms of the nature of companies, in Guangdong, the companies are mainly foreign-funded enterprises as well as Hong Kong, Macao and Taiwan capital. So the government, out of consideration of politics and investment promotion, is employer-friendly rather than neutral, suppressing the demand of the employees, which led to the accumulation of contradictions and was relatively intense at the time of the outbreak. (3) In terms of enterprise scale, in Guangdong, companies are mainly large and medium-sized enterprise, and the labor-management relationship is highly imbalanced, resulting in fierce conflicts when it breaks out for the long suppressed demand. (4) In regard to the geographical distribution of employees' hometown, the proportion of laborers from other provinces working in Guangdong is very high, and there are close connections among them - they have such natural connections as fellow-villagers and classmates, so the strength of groups is relatively strong. (5) In terms of the relationship between business owners and their middle

\footnotetext{
1 Although the policy changed in the past 5 years, Guangdong Model has no essential change except for that the government and local federation of trade unions are a little harsher with the strikers.

2 Nearly all strikes are led by middle-ranking managers who are covered and never admit that they are leaders of the strikes.
} 
ranking managers, most of Guangdong's business owners are outsiders or foreigners, while the middle managers are mostly from other provinces or even migrant workers without natural connections with their employers, so their relation is not close. (6) The external influence is that Guangdong has a high degree of openness to the outside world. Affected by external influences, especially Hong Kong, workers know more about organizing and strikes and skillful in strikes.

The characteristics of Guangdong Model collective disputes and the causes of the formation of Guangdong Model industrial relations have determined that the route for Guangdong to promote collective bargaining should be: direct election of grass-roots trade unions (as far as possible supplemented by legislation to confirm the right of trade unions to litigate on behalf of individual employees) enterprise-level collective bargaining legislation to confirm the right to strike industry-level collective bargaining.

\subsection{The Zhejiang Model $^{3}$}

According to my survey, combined with media reports and other scholars' research, the characteristics of Zhejiang Model industrial disputes can be summarized as follows: (1)The labor disputes begin with group job-hopping or group sabotage, and the sectoral trade union advocated collective bargaining follows as a result of joint-pricing of employers; (2) There are barely strikes; (3) The employers change their behavior from wage competition, joint pricing, to collective bargaining in industry; (4) Local federations of trade unions and governments rarely intervene in collective bargaining.

The causes of the formation of Zhejiang Model industrial relations are: (1) The degree of marketization is high, and the self-consciousness of laborers is strong; low proportion of state-owned enterprises and low wages of workers; (2) In terms of the nature of enterprises, enterprises in Zhejiang are mainly private enterprises, so the government is relatively neutral. Conflicts are easily resolved in time (both labor and capital parties resolve the matter on their own), so the conflicts are not fierce. (3) In terms of enterprise size, enterprises in Zhejiang are mainly small and micro-enterprises, and the degree of imbalance in industrial relations is low, so the conflicts are not fierce. (4) In terms of the proportion of laborers from other provinces, the proportion of employees from other provinces in Zhejiang is low, the relationship is relatively loose, the group strength is relatively weak. (5) In terms of the relationship between business owners and their relationship with middle ranking managers, business owners are mainly local people in Zhejiang, having closely contact, and the middle managers are mainly relatives and friends closely related. (6) In terms of external influences, Zhejiang has a low degree of openness to the outside world and is less affected by foreign influences, so the employees are accustomed to traditional job-hopping and sabotage.

The characteristics of Zhejiang Model industrial disputes and the causes of the formation of Zhejiang Model industrial

3 Although the policy changed in the past 5 years, Zhejiang Model has no essential change. relations have determined that the route for Zhejiang to promote collective bargaining should be: direct election of grass-roots trade unions (as far as possible supplemented by legislation to confirm the right of trade unions to litigate on behalf of individual employees) $\rightarrow$ development of trade unions in industry $\rightarrow$ industry-level collective bargaining $\rightarrow$ legislation to confirm the right to strike.

\section{Conclusion}

At present, in China, grass-root trade union reform is closely related to the promotion of collective bargaining. Only by activating the grass-root trade unions through reform can collective bargaining proceed smoothly. The reform of grass-root trade unions is not only inevitable and necessary, but also feasible; grass-root trade unions should be activated through direct elections of grass-root trade union and trade unions' representative litigation on behalf of individual workers. The way of collective bargaining itself is also very important. Guangdong Model and Zhejiang Model are good examples in collective bargaining. All localities ought to choose the right way according to local conditions.

\section{References}

[1] SHEN Xinwang, et al. Direct Election of Trade Unions inside Companies: Empower Workers. Procuratorial Daily, August 20, 2012, YANG Jie. Analysis on Direct Election of Trade Unions. Commerce, No. 24, 2014.

[2] FU Jianfeng. Direct Election: A Reform Driven by Foreign Companies. Southern Metropolis Daily, June 25, 2003).

[3] All-China Federation of Trade Unions. Opinions on Several Issues Concerning Advancing the Reform and Construction of Trade Unions (Trial) (GongFa (1997) No. 26).

[4] DENG Yuwen. Building a Harmonious Society Requires the Use of the Power of Trade Unions. Study Times, December 13, 2004.

[5] Article 46 of the Trade Unions Law stipulates, "The property, funds, and the real estate allocated to the trade union by the State shall not be invaded, misappropriated, or arbitrarily allocated by any organization or individual."

[6] Adopted at the 1263rd meeting of the Judicial Committee of the Supreme People's Court on January 9, 2003, and implemented on July 9, 2003.

[7] Xu Xiaohong, Chen Leyang. Analysis of the Reality of Direct Election of Union Chairs and the Relevant Regulations - taking a city in the south as an example. Journal of Beijing Trade Union Carder College, No. 4, 2005, Opinions of the General Office of the CPC Zhejiang Provincial Committee and the General Office of the People's Government of Zhejiang Province on Further Strengthening the Construction of Grassroots Trade Unions (ZheWeiBanFa〔2013 No. 5).

[8] Wang Kailei. Guangdong Pilots: Democratic Election of Grass-root Trade Union. Xinhua Daily Telegraph, July 3, 2014.

[9] Zhang Hao, Peng Yufei, Huang Ying. The Grass-root Trade Union is Created through True Democratic Elections. Nanfang Daily, May 25, 2012. 
[10] In 2010, Shanghai Municipal Federation of Trade Unions issued "Trade Union's Opinions on Further Promoting the Direct Election of Grassroot Trade Union Chairpersons" (HuGongZongZu [2010] No. 89).

[11] In 2014, Liaoning Provincial Federation of Trade Unions issued the "Interim Measures for the Direct Election of Trade Union Chairpersons at the Grassroots Level in Liaoning Province" (LiaoGongFa [2014] No. 25).

[12] Li Gangyin. Socialization of Rights Safeguarding: the Practice to Establish a New Mechanism for Defending Labor Rights by the Federation of Trade Unions of Yiwu City, Zhejiang Province. Workers Daily, January 19, 2005.

[13] Liu Cheng. Research on the Representative Litigation Right of Trade Unions. Journal of Haihe University, No. 2, 2010.
[14] Zhang Jianping and Qi Zhongxi. Direct Election of Grass-root Trade Union Chairpersons: Selecting Close Friends of Employees. September 25, 2003 http://www.people.com.cn/GB/shizheng/1026/2109507.html , September 13, 2018.

[15] Zhang Hao, Peng Yufei, Huang Ying. The Election of a Trade Union through True Democracy. Nanfang Daily, May 25, 2012.

[16] Liu Cheng. Legislation on Trade Unions' Representative Rights in Developed Countries and Its Revelation. Academia, No. 5, 2006.

[17] Liu Cheng. Collective Bargaining and Trade Unions' Representation. Social Science Front, No. 4, 2012. 